\title{
The Effect of School Environment, Family Environment and Learning Motivation on Students' Learning Performance
}

\author{
Jefri Kurniawan ${ }^{1}$, Z. Mawardi Effendi², Sany Dwita ${ }^{3}$ \\ ${ }^{1}$ Faculty of Economics, Universitas Negeri Padang, Padang, Indonesia, \\ $\square$ (e-mail) Universitas Negeri Padang, Padang, Indonesia, $\square$ (e-mail) jefri29.jk@gmail.com \\ 2Department of Economics Education, Faculty of Economics, Universitas Negeri Padang, Indonesia, \\ $\bowtie$ (e-mail) zmeffendi@gmail.com \\ 3Department of Accounting, Faculty of Economics, Universitas Negeri Padang, Padang, Indonesia, \\ $\square$ (e-mail) sany@fe.unp.ac.id
}

\begin{abstract}
This study is motivated by the students' low learning outcomes in accounting subject. This is allegedly caused by the less conducive school environment and family environment and the relatively low learning motivation. This study is a descriptive associative research with the population of 75 accounting students of 12th grade in state vocational high school (Sekolah Menengah Kejuruan Negeri-SMKN) Bismen, Tanah Datar. The sample was selected by using random sampling technique with a total sample of 64 students. The data were collected using a survey questionnaire. The data were analyzed using path analysis. The results showed that 1) there is a significant influence of school environment on students' learning motivation, 2) there is a significant influence between family environment on students' learning motivation, 3) there is a significant influence between the school environment on students' learning outcomes, 4) there is a significant influence of family environment on learning performance of XII AK students of SMK Bismen Tanah Datar, 5) there is a significant influence between learning motivation on learning performance of XII AK students in SMK Bismen, Tanah Datar.
\end{abstract}

Keywords: family environment, learning motivation, school environment and learning performance

\section{Introduction}

Students' performance in accounting subject at SMKN Bismen Tanah Datar has not yet reached the satisfying level. Based on a preliminary study, the students' average scores from their daily tests were of 58.19 for class XII.AK ${ }_{1}$, followed by class XII.AK 2 with 57.18 and class XII.AK 3 with 57.87 . it is clear that students' average scores were far below the minimum standard criteria required by the school. The minimum standard criteria set by SMKN Bismen Tanah Datar is 80, this applies to all subjects including Accounting. The poor accounting learning performance can be attributed to many factors, namely, internal and external factors. The internal factor consists of physical factors, intelligence, interest and attention, motivation to learn, perseverance, attitude, study habits, and physical and health conditions. Whereas, external factors derived from outside the students themselves that affect student learning outcomes are family, school and community (Slameto, 2010 and Susanto, 2013).

External factors that affect student learning outcomes are the less conducive school environment. Sutarti (2016) shows that the school environment has a positive and significant impact on student learning outcomes. The facilities and infrastructure in the school are needed in the learning process. Incomplete facilities and infrastructure make the learning process hampered. The facilities and infrastructure in SMKN Bismen Tanah Datar is still insufficient. There are some computers that are out of service and the total availability is not in sufficient for the number of students. The number of accounting books is not sufficient for the total number of students.

Furthermore, the learning method used by teachers in delivering materials to students greatly affect students' performance, especially with regards to students' learning motivation. Accounting 
teachers tend to use the teacher-centered method, so that students are less active in the learning process.

The other external factors that affect student learning outcomes is the family environment. Sutarti (2016) shows that the family environment has a positive and significant impact on students' learning outcomes. Similarly, Minhayati (2014) and Egunsola (2014) show that family factor has a positive and significant effect on academic results students. The family environment gives the first influence in the formation of one's personality. The family is where the first learning process takes place; thus, it is expected to instigate good learning habits. However, the family environment can negatively impact learning performance when there is lack of support on study habits and discipline in it. Family environment, especially parents, plays a big role, because they are directly related to children. Parents has a big influence on students' learning success. According to Indrakusuma and Daien (2003, 123), the high level of parental education, the size of parents' income, the familiarity of parents' relationship with children affect students' learning success.

There are also internal factors derived from within that can affect students' learning outcomes. One of those is the student's learning motivation. According to Alderfer in Nashar (2004:42) explains that motivation is the tendency of students in learning activities that are driven by the desire to achieve the results or learning outcomes as good as possible. Sutarti (2016) provides empirical evidence that students' learning motivation has a positive and significant impact on students' learning outcomes. Nova (2017) shows that there is a significant correlation between learning motivation and learning environment on students' learning achievement. Learning motivation in students will also determine the results they can achieve. According to Nashar (2004,11), the students' learning motivation is instrumental to improve students' learning outcomes in certain subjects. Students who have high learning motivation are likely to get high results, because motivated students will try as hard as possible to get what they want.

Based on the above statements, this study aims to examine the influence of school environment, family environment, and learning motivation on students' accounting learning performance in SMKN Bismen Tanah Datar.

The hypotheses proposed in this study are as follows.

$\mathrm{H}_{1}$ school environment has a significant effect on students' learning motivation

$\mathrm{H}_{2}$ family environment has a significant influence on students' learning motivation

$\mathrm{H}_{3}$ school environment has a significant effect on students' learning performance

$\mathrm{H}_{4}$ family environment has a significant influence on students' learning performance H5 learning motivation has a significant effect on students' learning performance

\section{Methods}

This study is a descriptive and associative research. The population of this research was 75 accounting students in 12th grade at SMK Bismen Tanah Datar. The sampling in this study was chosen by proportional random sampling technique using Slovin formula with a total sample of 64 students.

A research instrument was used to measure school environment, family environment and learning motivation. This questionnaire was distributed to all sample. The questionnaire was designed to elicited responses in 5-point Likert scale. The questionnaire is based on indicators of each variables being tested in this study, namely, school environment, family environment and learning motivation.

The questionnaire has been pilot tested for its validity and reliability to make sure that the questionnaire can be used as a good data collection tool. The pilot test results were interpreted using Pearson product moment analysis for the items' validity and Cronbach alpha analysis for its reliability. 
Reliability is a measure that indicates the level of validity of an instrument (Arikunto, 2010, 11). An instrument is considered to be valid if it meets the validity score criteria. In contrary, an invalid instrument means one who has low validity score. An item is valid if it can measure what it is supposed to measure.

Based on the results of the pilot test, there were 3 items eliminated from 25 statements related to school environment. Further, there were 2 items eliminated from 21 statements related to family environment. Finally, there were 4 items eliminated from 40 statements related to the learning motivation.

According to Arikunto $(2010,178)$, an instrument is considered reliable if it generates consistent and stable results. Reliability is a requirement for the validity of a test. Unreliable tests are by itself invalid. Reliability testing of this instrument was done by using Cronbach alpha (Idris, 2008, 8) because the questionnaire was written in open question. The formula can be written as follows.

$$
r_{11}=\left[\frac{k}{k-1}\right]\left[\frac{\sum \sigma b^{2}}{\sigma^{2}}\right]
$$

The results of reliability test showed that questionnaire for school environment, family environment and learning motivation had Cronbach alpha of 0.910, 0.902, and 0959, respectively. Therefore, it can be concluded that the research questionnaire was reliable.

This study continued with a survey to the sample students to collect data with regards to school environment, family environment and learning motivation. Moreover, the study used the list of students' accounting test scores in the odd semester 2017/2018 for the students' performance data. The data were analyzed using parametric test of path analysis method to test the proposed hypotheses. In particular, path analysis is used to explain the direct and indirect effects of a set of exogenous variables on endogenous variable.

\section{Results and Discussion}

A preliminary analysis, namely, normality and homogeneity tests were conducted. The results show no issues and that the data adhere the requirements for path analysis. The analysis then continued with hypotheses testing.

The first stage of analysis was aimed at examining the effect of school environment $\left(X_{1}\right)$ and family environment $\left(\mathrm{X}_{2}\right)$ on learning motivation $\left(\mathrm{X}_{3}\right)$ of Accounting students in class XII.AK at SMK Bismen Tanah Datar. The results are as follows.

Table 1 The summary of path coefficient

\begin{tabular}{lcccc}
\hline \multicolumn{1}{c}{ Variable } & coefficient & $t_{\text {count }}$ & $F_{\text {count }}$ & Sig \\
\hline $\begin{array}{l}\text { School environment }\left(\mathrm{X}_{1}\right) \rightarrow \text { learning } \\
\text { motivation }\left(\mathrm{X}_{3}\right)\end{array}$ & 0.409 & 3.605 & 8.705 & 0.001 \\
$\begin{array}{l}\text { Family environment }\left(\mathrm{X}_{2}\right) \rightarrow \text { learning } \\
\text { motivation }\left(\mathrm{X}_{3}\right)\end{array}$ & 0.274 & 2.415 & & 0.019 \\
\hline
\end{tabular}

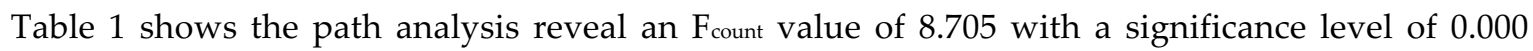
which is lower than alpha 0.05 . This shows that school environment and family environment have a significant simultaneous effect on learning motivation, and further allows the partial analysis.

The results of partial analysis show path coefficient of each exogenous variables (school and family environment) in its relation to students' learning motivation as follows. The effect of school environment on students' learning motivation $\left(\mathrm{pX}_{1} \mathrm{X}_{3}\right)$ has a path coefficient of 0.409 with a significance level of 0.001 which is lower than alpha 0.05 . It can be interpreted that school environment has a significant effect on students' learning motivation. It implied that the improvement in school environment will lead to the improvement in students' learning motivation. 
School social environments such as teachers, administrative staff, and classmates can influence a student's learning spirit. If teachers always show sympathetic attitudes and behaviors as well as demonstrate good role models, especially in learning, can be a positive impetus for students' learning activities (Shah, 2003: 152).

Further, the results show that the effect of family environment on students' learning motivation $\left(\mathrm{pX}_{2} \mathrm{X}_{3}\right)$ has a path coefficient of 0.274 with a significance level of 0,019 which is lower than alpha 0.05 . It can be concluded that family environment has a significant effect on students' learning motivation. This means that the improvement in family environment will lead to the improvement in students' learning motivation.

The family environment is the students' first environment and it affects students as an individual. According to Ahmadi $(2007,167)$, family is a small social group consisting mostly of fathers, mothers and children with relatively fixed social relationships and is based on blood, marriage and/ or adoption bonds. Munib $(2011,77)$ stated that family is the first and foremost environment because before an individual gets into other educational institutions. This is the first environment that grooms them as a human and shape their personality as well as character.

Slameto $(2010,60-64)$ stated that students who learn will receive influence from the family in the way parents educate, the relationship between family members, home atmosphere, family economic conditions, understanding parents, and cultural background. Thus, a good family environment is needed to encourage student to achieve more and serves as a motivation, therefore students will be more driven to do well in their education.

This study then continued with the second stage of analysis which was aimed at examining the effect of school environment $\left(X_{1}\right)$ and family environment $\left(X_{2}\right)$ and learning motivation $\left(X_{3}\right)$ on students' accounting learning performance (Y) in class XII.AK at SMK Bismen Tanah Datar. The results are presented in Table 2 .

Table 2 Summary of path coefficient on the influence of each exogenous variable to the endogenous variable

\begin{tabular}{lcccc}
\hline \multicolumn{1}{c}{ Variables } & $\begin{array}{c}\text { Path } \\
\text { Coefficient }\end{array}$ & tcount & Fcount & Sig. \\
\hline $\begin{array}{l}\text { School environment }\left(\mathrm{X}_{1}\right) \rightarrow \text { learning } \\
\text { performance }(\mathrm{Y})\end{array}$ & 0.258 & 2.211 & & 0.031 \\
$\begin{array}{l}\text { Family environment }\left(\mathrm{X}_{2}\right) \rightarrow \text { learning } \\
\text { performance }(\mathrm{Y})\end{array}$ & 0.252 & 2.272 & 9.882 & 0.027 \\
$\begin{array}{l}\text { Learning motivation }\left(\mathrm{X}_{3}\right) \rightarrow \text { learning } \\
\text { performance }(\mathrm{Y})\end{array}$ & 0.328 & 2.741 & & 0.008 \\
\hline
\end{tabular}

Table 2 shows a Fcount value of 9.882 with a significance level of 0.000 which is lower than alpha 0.05. This shows that school environment, family environment, and students' learning motivation have a significant simultaneous effect on learning performance. The results allow this study to proceed with the partial analysis.

The results of partial analysis show are as follows. First, the effect of school environment on students' learning performance $\left(\mathrm{pX}_{1} \mathrm{X}_{3}\right)$ has path coefficient of 0.258 with significance level of 0,031 which is lower than alpha 0.05 . It can be interpreted that school environment has a significant effect on students' learning performance. Based on the hypothesis testing explained in the pevious section, it can be seen that there is a significant link between the school environment on students' learning motivation for 12th grade Accounting students in SMK Bismen Tanah Datar. The influence of school environment on students' learning motivation is positive. This means that the higher the score of school environment, the higher the students' motivation is. 
The results clearly show that school environment has a positive significant effect on learning performance of accounting students at SMK Bismen Tanah Datar. This means that better the school environment, the better students' learning performance.

According to Slameto $(2010,64)$, school factors that affect learning include teaching method, curriculum, teacher relationships with students, student relationships, school disciplines, lessons and school time, standard lessons, building conditions, learning methods and homework. According to Ahmadi (2007, 33), a good school environment is a challenging environment that stimulates students to learn, provide a sense of security and satisfaction and support them to achieve the expected goals.

Second, the effect of family environment on students' learning performance $\left(\mathrm{pX}_{2} \mathrm{X}_{3}\right)$ has a path coefficient of 0.252 with a significance level of 0,027 which is lower than alpha 0.05 . It can be concluded that family environment has a significant effect on students' learning performance.

The results are in accordance with the Sangalang as cited in Kartono (1990, 1-6) who explained that factors affecting student achievement consist of intelligence, talent, interest and attention, motivation, health condition, way of learning, family environment, schools and learning support facilities. So, family environment is one of the factors that will affect students' achievement. This means that all things related to family, such as how the parents educate their children, relationships among family members, comfortable home atmosphere, family economic conditions, and learning facilities that support the learning, it will all promote a better learning performance in students, and vice versa, if students are surrounded with the environment that actually distracts their focus from learning, it will weigh down their learning performance.

According to Indrakusuma and Daien, $(2003,123)$, the level of parental involvement in education, the level of the parents' income, and the intimacy of the parents' relationship with the children affect the students' degree of success. In other words, parents play an important role in the success of their offspring's education.

Third, the effect of learning motivation on students' learning performance $\left(\mathrm{p}_{2} \mathrm{X}_{3}\right)$ has a path coefficient of 0.328 with a significance level of 0.008 which is lower than alpha 0.05 . The results suggest that learning motivation has a significant effect on students' learning performance.

Mulyasa $(2010,174)$ reveals that motivation is one of the factors that can improve the quality of learning, because students will learn earnestly if they have high motivation. The motivation invested in students will be something that drives them to do something in relation to the degree of their learning performance. In line with the above statement Ting Lin and Min Jou (2013, 157), state enhancing student learning motivation is important for the teaching and learning of new knowledge or skills because motivation affects how instructors and students interact with learning materials. Improving students' learning motivation is important for learning process because motivation will affect how teachers and students interact with learning materials. Therefore, in order to be able to improve the quality of learning, teachers should be able to motivate students to be more actively engaged during the learning process.

The results of this study in line with Sutarti (2016) who shows that the motivation to learn has a positive and significant impact on student learning outcomes. Moreover, Nova (2017) shows that there is a significant influence between learning motivation and learning environment on learning achievement.

\section{Conclusions}

This study aims to examine the effect of school environment, family environment and learning motivation on students accounting performance. This study is a descriptive associative research with the population of 75 accounting students of 12th grade in state vocational high school (Sekolah Menengah Kejuruan Negeri-SMKN) Bismen, Tanah Datar. The sample was selected by using random 
sampling technique with a total sample of 64 students. The data were collected using a survey questionnaire and analyzed using path analysis.

Several important results of this study are as follows. First, there is a significant influence of school environment on students' learning motivation. Second, there is a significant influence between family environment on students' learning motivation. Third, there is a significant influence between the school environment on students' learning outcomes. Fourth, there is a significant influence of family environment on learning performance. Finally, there is a significant influence between learning motivation on learning performance of XII AK students in class XII at SMK Bismen, Tanah Datar.

\section{References}

Ahmadi, Abu. (2007). Psikologi Sosial. Jakarta: PT. Rineka Cipta.

Arikunto, Suharsimi. (2010). Prosedur Penelitian Suatu Pendekatan Praktek. Jakarta: Rineka Cipta

Kartini Kartono. (1990). Psikologi Perkembangan Anak. Bandung: CV. Mandar.

Idris. (2008). Pelatihan Analisis SPSS. Himpro Manajemen Fakultas Ekonomi UNP: Padang.

Indrakusuma \& Daien, Amier. (2003). Pengantar Ilmu Kependidikan. Surabaya: Usaha Nasional.

Nashar, H. (2004). Peranan Motivasi \& Kemampuan Awal. Jakarta: Delia Press.

Slameto. (2010). Belajar dan Faktor-Faktor yang Mempengaruhinya. Jakarta: Rineka Cipta.

Susanto, Ahmad. (2013). Teori Belajar Pembelajaran. Jakarta: Kencana Prenada Media Group

Sutarti. (2016). Pengaruh Kompetensi Guru, Motivasi Belajar, Dan Lingkungan Keluarga Terhadap Hasil Belajar Mata Pelajaran Ekonomi. Harmoni Sosial: Jurnal Pendidikan IPS. 3 (2), 188-198.

Syah, Muhibbin. (2010). Psikologi Pendidikan Dengan Pendekatan Baru. PT Remaja Rosdakarya. 